\title{
EFFECT OF DIETARY KEFIR ON THE DIGESTIVE AND LIVER ENZYMES ACTIVITIES AND GLUCOSE LEVEL OF CORUH TROUT, SALMO CORUHENSIS (ACTINOPTERYGII: SALMONIFORMES: SALMONIDAE)
}

\author{
Safak SEYHANEYILDIZ CAN ${ }^{1}$, Filiz KUTLUYER ${ }^{2 *}$, Erkan CAN ${ }^{2}$, Şevki KAYIŞ ${ }^{3}$, Fatma \\ DELİHASAN SONAY ${ }^{3}$, Özay KÖSE ${ }^{3}$, Önder AKSU ${ }^{2}$, Hüsamettin ERDAMAR ${ }^{4}$, \\ M. Ramazan YİĞİTOĞLU ${ }^{4}$, and Murathan KAYIM ${ }^{2}$ \\ ${ }^{1}$ Engineering Faculty, Bioengineering Department, Tunceli University, Tunceli, Turkey \\ ${ }^{2}$ Fisheries Faculty, Tunceli University, Tunceli, Turkey \\ ${ }^{3}$ Fisheries Faculty, Recep Tayyip Erdoğan University, Rize, Turkey \\ ${ }^{4}$ Faculty of Medicine and Medical Biochemistry, Turgut Özal University, Ankara, Turkey
}

\begin{abstract}
Seyhaneyildiz Can S., Kutluyer F., Can E., Kayiş Ş., Delihasan Sonay F., Köse Ö., Aksu Ö., Erdamar H., Yiğitoğlu M.R., Kayim M. 2014. Effect of dietary kefir on the digestive and liver enzymes activities, and glucose level of Coruh trout, Salmo coruhensis (Actinopterygii: Salmoniformes: Salmonidae). Acta Ichthyol. Piscat. 44 (2): 167-170.
\end{abstract}

Background. The probiotics are very important for aquaculture because of their role in enhancing the fish health status, improving disease resistance, growth performance, and body composition, reducing malformations, improving gut morphology and the overall microbial balance. The objective of the presently reported study was to investigate effects of kefir as a probiotic product on the digestive and hepatic enzyme activities, as well as glucose level of Coruh trout, Salmo coruhensis Turan, Kottelat et Engin, 2010. The experiment was performed with four treatments: control group (no kefir), D1, D2, and D3 (kefir-supplemented diet: 10, 20, and $40 \mathrm{~g} \cdot \mathrm{kg}^{-1}$ fish body mass, respectively). The activity of: alanine aminotransferase (ALT), aspartate aminotranferase (AST), lactate dehydrogenase (LDH), lipase, amylase - as well as the glucose levels were determined after 4 months. The results indicated that glucose levels $(P<0.05)$ and digestive enzymes (lipase and amylase) in the blood serum decreased in fish fed diets containing kefir $(P>0.05)$. On the contrary, the activity of liver enzymes (ALT, AST, and LDH) increased insignificantly $(P>0.05)$. In conclusion, digestive and liver enzyme activities were affected by quantitative changes in dietary kefir insignificantly but further research is needed to establish whether the liver and digestive enzyme physiology of Coruh trout can be affected by kefir-supplemented diets in a long-term trial.

Keywords: Coruh trout, Salmo coruhensis, probiotic, alanine aminotransferase, aspartate aminotranferase, Lactate dehydrogenase, blood

Dietary probiotics are considered environment-friendly and can be beneficial for the aquatic animals through: improving their disease resistance and reducing malformations; increasing their growth performance, body composition; improving their gut morphology as well as the microfloral balance (Suzer et al. 2008, Merrifield et al. 2010, Ekici et al. 2011). The majority of probiotics have the ability to survive the passage through the intestinal tract (Verschuere et al. 2000). The probiotic bacteria produce vitamin and important digestive enzymes and provide minerals and trace elements (Holzapfel et al. 1998). Kefir, which is a probiotic product, became most popular feed additive for humans and recently also for animals (Güven et al. 2003). Kefir alters the intestinal microflora and thus exerts beneficial health effect on the exposed organism (Schrezenmeir and de Vrese 2001) and stimulates digestion of other foods, decreases the cholesterol content in blood and improves salivation and excretion of gut and pancreatic enzymes and peristalsis (Anonymous 2013).

Hematological parameters such as activity of enzymes (alanine aminotransferase, ALT; aspartate aminotransferase, AST; lactate dehydrogenase, LDH; lipase, amylase) and glucose level are used as indicators of the physiological status of fish (Bansal et al. 1979).

The salmonid species - Coruh trout, Salmo coruhensis Turan, Kottelat et Engin, 2010 - which was only recently

\footnotetext{
* Correspondence: Dr Filiz Kutluyer, Su Ürünleri Fakültesi, Tunceli Üniversitesi, Tunceli, 62000, Turkey, phone: +904282131794-1237, e-mail: (FK) filizkutluyer@hotmail.com, (ŞSC) seyhaneyildiz@tunceli.edu.tr, (EC) erkancan@tunceli.edu.tr, (ŞK) aquasevki@msn.com, (FDS)fatmadelihasan@gmail.com, (ÖK) ozaykose@msn.com,(ÖA) onderaksu@tunceli.edu.tr, (HE)mdherdamar@yahoo.com,(MRY)ryigitoglu@turgutozal.edu.tr, (MK)murathankayim@gmail.com.
} 
described, has already gained interest of aquaculturists. The feeding regimes of this new fish have been inadequately studied, including the effect of probiotic substances such as kefir. Information regarding the enzyme producing intestinal bacteria, their source and their effect on fish digestion and metabolism is limited. Can et al. (2012) studied the effects of different dosage of kefir with different durations (2-month and 3-month treatment) on growth performances and antioxidant system of Coruh trout. In the wake of the above-mentioned studies, we examined the effects of dietary kefir with different concentrations on digestive and liver enzymes activities and glucose level of Coruh trout, which is a new species for aquaculture (Başçınar et al. 2010). In addition, the presently reported study was also conducted to investigate the relevant physiological changes.

The experiments were conducted at the Aquaculture Department of the Recep Tayyip Erdoğan University Faculty of Fisheries, Rize, Turkey. The fish ( $n=90,9.0 \pm$ $0.1 \mathrm{~g}$, mean \pm standard error of the mean) were equally stocked into 12 tanks (50 L), and fed for 12 weeks. There were three replicate tanks per treatment and the flow rate was $30 \mathrm{~L} \cdot \mathrm{min}^{-1}$. The intake water temperature was 11.4 $\pm 2.2^{\circ} \mathrm{C}$. The values of $\mathrm{pH}$ and dissolved oxygen were 7.93 $\pm 0.18(7.71-8.19)$ and $7.83 \pm 1.32(6.15-10.01) \mathrm{mg} \cdot \mathrm{L}^{-1}$, respectively. The photoperiod was not regulated (regional autumn natural cycle). The fish were fed with $3 \%$ feeding rate of body weight three times a day. The kefir contents of the diet 1 , diet 2 , and diet 3 were $10 \mathrm{~g} \cdot \mathrm{kg}^{-1}, 20 \mathrm{~g} \cdot \mathrm{kg}^{-1}$ and $40 \mathrm{~g} \cdot \mathrm{kg}^{-1}$, respectively. No kefir was added to control diet.

Kefir grains were isolated and identified in our laboratory. The lactic acid bacteria isolated from kefir grains were identified as Lactobacillus helveticus and Leuconostoc mesenteroides, and the yeasts are identified as Kluyveromyces marxianus and Pichia fermentans. They were propagated at $4^{\circ} \mathrm{C}$ for $24 \mathrm{~h}$. Raw milk, obtained from a special dairy farm was heated to $90^{\circ} \mathrm{C}$ for $10 \mathrm{~min}$ in a water bath, before cooling down to inoculation temperature. The heat-treated milk was inoculated with $5 \%(\mathrm{v} / \mathrm{w})$ kefir grains and incubated at $22^{\circ} \mathrm{C}$ for $20 \mathrm{~h}$ (Güven et al. 2003). Then kefir was mixed with commercial trout feed (45\% crude protein, $19 \%$ crude lipids, $3 \%$ crude cellulose, 12\% moist, and 13\% ash) (Bioaqua, Pınar Yem, Turkey, Standard extruded trout feed) and then feed was covered with fish oil by spray drying $(32 \mathrm{~mL}$ fish oil per $\mathrm{kg}$ of feed).

For enumeration of the microorganisms present in the kefir preparations, a $25 \mathrm{~mL}$ kefir sample was diluted with $225 \mathrm{~mL}$ peptone water (Oxoid Ltd., Hampshire, UK) and combined uniformly in a vortex mixer. Subsequent serial dilutions were prepared and viable numbers of the microorganisms were counted using the pour-plate technique. Samples were plated on dextrose agar (Oxoid, CM139) for yeasts and on Mann Rogosa Sharpe (MRS) agar (Merck, Germany) for lactic acid bacteria.

Blood was collected from the caudal vein using sterile disposable plastic syringe with an 18-gauge needle.
Serum was obtained by blood centrifugation at $3000 \mathrm{rpm}$ for $15 \mathrm{~min}$. The samples were kept at $4^{\circ} \mathrm{C}$ and $-80^{\circ} \mathrm{C}$ for determination of ALT-, AST-, LDH-, lipase-, and amylase activities and glucose level. All parameters were analyzed by Roche Cobas Mira Plus Chemistry Analyzer (Roche Diagnostics Ltd. W Sussex, UK), with colorimetric methods with commercial kits (Sigma Diagnostics, Madrid, Spain).

The results are given as mean \pm standard error of the mean. Differences among dietary treatments for enzymatic values were compared by one-way ANOVA followed by Kruskal-Wallis multiple range test. All tests were performed using SPSS 15.0 software.

The experimental procedures were approved by the Animal Care Committee of the Faculty of Veterinary Medicine, Firat University, Turkey.

Changes of ALT-, AST-, LDH-, lipase-, and amylase activities and glucose levels of Coruh trout, Salmo coruhensis, are shown in Fig. 1. The results of the presently reported study indicated that AST and LDH activity in
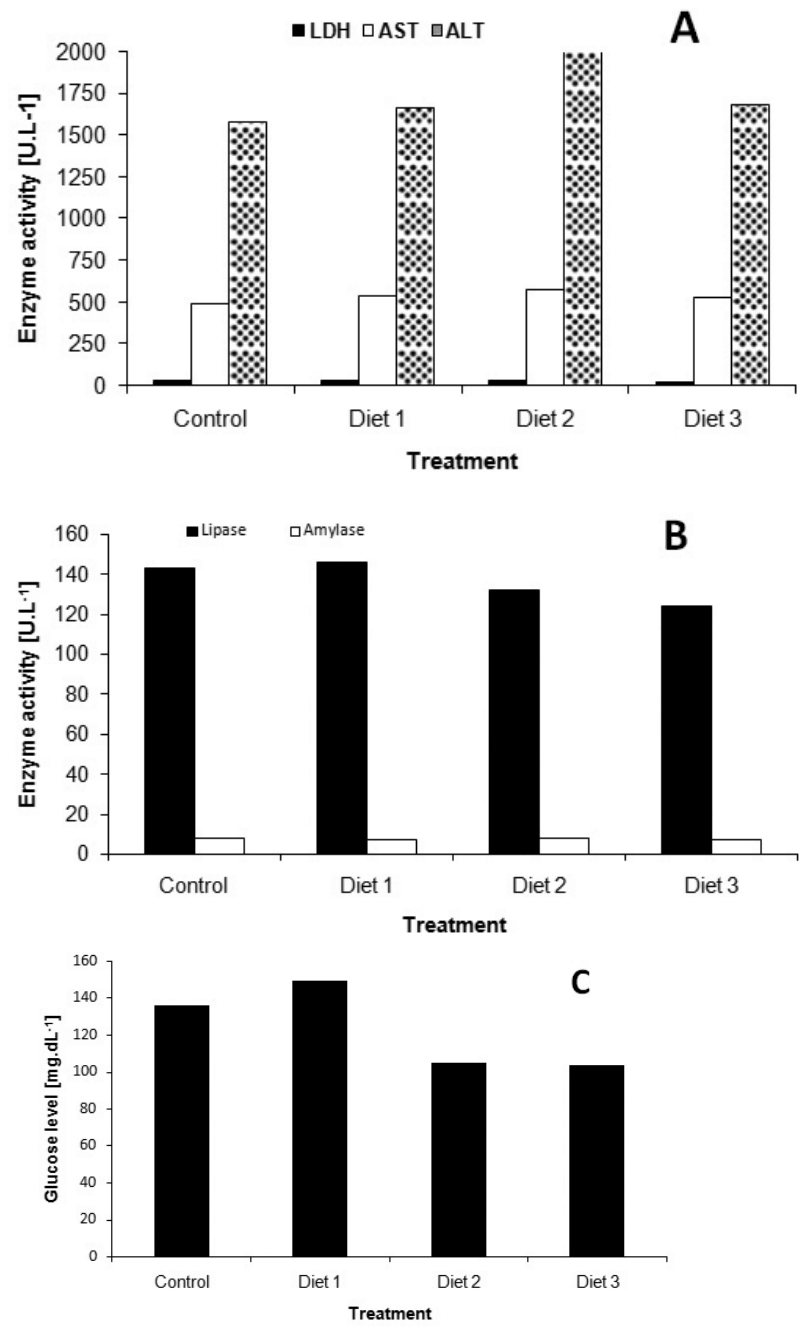

Fig. 1. Changes of ALT-, AST-, LDH-, lipase-, and amylase activities and glucose levels of Coruh trout, Salmo coruhensis, cultured with four feeding regimes (kefirsupplemented diet 10,20 , and $40 \mathrm{~g} \cdot \mathrm{kg}^{-1}$ fish body mass) over 120 days 
the blood increased when Coruh trout were fed diets: 2,3 , and 4. ALT activity in blood decreased in Coruh trout fed diet 3 and diet 4 compared to control diet, but the differences were not significant statistically (Fig. 1a). Amylase and lipase activity in the blood decreased in all treatment groups, except for diet 2 . The lowest amylase activity was observed in Coruh trout fed diet 3 (Fig. 1b). On the other hand, the highest glucose level was observed in Coruh trout fed diet $1(P<0.05)$ (Fig. 1c). The quantities of lactic acid bacteria (Lactobacillus spp.) lactic streptococci, and yeasts were determined as $1.0 \times 10^{8}, 2 \times 10^{-7}$, and 3 $\times 10^{7} \mathrm{CFU} \cdot \mathrm{mL}^{-1}$, respectively.

Determination of enzyme activity plays a key role in monitoring fish health (Satheeshkumar et al. 2012). Serum biochemistry can be influenced by biotic and abiotic factors (Jawad et al. 2004). Scholl et al. (2006) suggests that damage of the liver and muscle tissues by an excessive stress causes the appearance of AST, ALT, GGT, and LDH in the serum. Probiotics are likely to enhance the health status of fish. Can et al. (2012) reported that kefir plays an antioxidant role and its effectiveness depends on dosage and time of application in Coruh trout.

The knowledge on the presence and levels of digestive enzymes is important for rapid and efficient growth rates in aquaculture due to digestion and absorption of nutrients and status of these enzymes can be changed by feed and feed additives (Srichanun et al. 2012). Supplementation of the diet with a probiotic provides bacteria to survive passage through the intestinal tract (Fuller 1992). Microorganisms and their enzymes are important in the digestion process (Munilla-Moran et al. 1990) due to increasing total enzyme activity of the gut (Ziaei-Nejad et al. 2006). Suzer et al. (2008) reported that an increase in activities of digestive enzymes was observed in gilthead seabream, Sparus aurata L., larvae treated with probiotic, Lactobacillus spp. In the presently reported study, however, amylase and lipase activities in all treatment groups were not significantly different. But kefir could have a different mechanism that help digestion independent of digestion enzymes, because some authors reported that kefir plays an important role in digestion (Hertzler and Clancy 2003, Anonymous 2013).

Glucose as an indicator of stress and plasma glucose concentration is commonly used to measure the fish welfare, reflecting different functional systems for farmed fish (Turnbull et al. 2005). Under stressful rearing conditions, glucose level increases in the fish blood. For example, plasma glucose increased in Atlantic salmon, Salmo salar L., after 7 days without food (Bell et al. 2002). ElRhman et al. (2009) found that glucose level in plasma increased in Nile tilapia, Oreochromis niloticus (L.), when two strains of bacteria (Micrococcus luteus and Pseudomonas spp.) were added to fish feed. On the contrary, the presently reported study showed that kefir decreased the level of serum glucose. Bacteria in kefir may improve the glucose level through inhibiting the production of several mediators such as reactive oxygen metabolites (ROMs) and cytokine, which are responsible for the destruction of pancreatic cells. Additionally, it may lower glucose level due to decrease in the intestinal absorption of carbohydrates through increasing the acarbose (AC) effect (Harisa et al. 2009).

AST, ALT, and LDH enzymes are abundant in liver (Vaglio and Landriscina 1999) and activities of these enzymes increase when some organs (liver, spleen, muscle, or kidney) are damaged. AST-, ALT-, and LDH activities decreased significantly in plasma of Nile tilapia, Oreochromis niloticus, when two strains of probiotic bacteria (Micrococcus luteus and Pseudomonas spp.) were added to fish feed (El-Rhman et al. 2009). On the other hand, in another study, the serum aspartate aminotransferase and alanine aminotransferase levels significantly increased when the fish were fed with Lactobacillus plantarum-, Lactobacillus acidophilus-, or Saccharomyces cerevisiae-supplemented diet in olive flounder, Paralichthys olivaceus (Temminck et Schlegel, 1846) (see Harikrishnan et al. 2011). Similarly, in the presently reported study, the levels of AST, LDH, and ALT increased insignificantly in the fish plasma. It can be concluded that kefir could increased stress and caused a higher enzyme activity. This study represents data on the status of the digestive and liver enzymes (amylase, lipase, glucose, AST, ALT, and LDH) of Coruh trout fed diets containing different levels of kefir. Our results indicate that the digestive and liver enzyme activities were insignificantly affected by quantitative changes in dietary kefir. We expect that this information will help to explain the effect of kefir on the enzyme activities and will improve health status of fish in order to reach a maximum production capacity in aquaculture. Further studies are needed, however, to investigate the role of kefir supplementation on the liver and digestive enzyme physiology and the nutrient utilization in fish.

\section{ACKNOWLEDGEMENT}

The authors wish to thank Dr. İlker Zeki Kurtoğlu for his efficient technical contribution towards conducting of the experiments.

\section{REFERENCES}

Anonymous 2013. Digestive health. National Kefir Association. [Accessed on 08 December 2013.] http://nationalkefirassociation.com/HealthandWellness/ DigestiveHealth.aspx

Bansal S.K., Verma S.R., Gupta A.K., Dalela R.C. 1979. Physiological dysfunction of the haemopoietic system in a fresh water teleost, Labeo rohita, following chronic chlordane exposure. Part I-Alterations in certain haematological parameters. Bulletin of Environmental Contamination and Toxicology 22 (1): 666-673. DOI: 10.1007/BF02027005

Başçınar N., Kocabaş M., Şahin Ş.A., Okumuş İ. 2010. Comparison of hatching performances and yolk sac absorptions of Black Sea trout (Salmo trutta labrax Pallas, 1811), brook trout (Salvelinus fontinalis Mitchill, 1814) and their hybrid. Kafkas Üniversitesi Veteriner Fakültesi Dergisi 16 (Suppl. B): S205-S209. 
Bell A., Bron J., Turnbull J.F., Adams C.E., Huntingford F.A. 2002. Factors influencing the welfare of farmed Atlantic salmon (Salmo salar) in commercial marine cages. Research in Veterinary Science 72 (Suppl. 1): 7-8. DOI: 10.1016/S0034-5288(02)90023-8.

Can E., Kurtoğlu İ.Z., Benzer F., Erişir M., Kocabaş M., Kızak V., Kayım M., Çelik H.T. 2012. The effects of different dosage of kefir with different durations on growth performances and antioxidant system in the blood and liver tissues of Çoruh trout (Salmo coruhensis). Turkish Journal of Fisheries and Aquatic Sciences 12: 277-283. DOI: 10.4194/1303-2712-v12_2_12.

Ekici S., Diler Ö., Didinen B.I. Kubilay A. 2011. Balıklardan izole edilen bakteriyel patojenlere karşı bazı bitkisel uçucu yağlarının antibakteriyal aktivitesi. ["Antibacterial activity of essential oils from medicinal plants against bacterial fish pathogens."] Kafkas Üniversitesi Veteriner Fakültesi Dergisi 17 (Suppl. A): S47-S54. [In Turkish.]

El-Rhman A.M.A., Khattab Y.A.E., Shalaby A.M.E. 2009. Micrococcus luteus and Pseudomonas species as probiotics for promoting the growth performance and health of Nile tilapia, Oreochromis niloticus. Fish and Shellfish Immunology 27 (2): 175-180. DOI: 10.1016/j.fsi.2009.03. 020 .

Fuller R. 1992. History and development of probiotics. Pp.1-8. In: Fuller R. (ed.) Probiotics: the scientific basis. Chapman and Hall, London, UK. DOI: 10.1007/978-94-011-2364-8_1.

Güven A., Güven A., Gülmez M. 2003. The effect of kefir on the activities of GSH-Px, GST, CAT, GSH and LPO levels in carbon tetrachloride-induced mice tissues. Journal of Veterinary Medicine, Series B 50 (8): 412-416. DOI: 10.1046/j.1439-0450.2003.00693.x

Harikrishnan R., Kim M.-C., Kim J.-S., Balasundaram C., Heo M.-S. 2011. Immunomodulatory effect of probiotics enriched diets on Uronema marinum infected olive flounder. Fish and Shellfish Immunology 30 (3): 964-971. DOI: 10.1016/j.fsi.2011.01.030

Harisa G.I., Taha E.I., Khalil A.F., Salem M.M. 2009. Oral administration of Lactobacillus acidophilus restores nitric oxide level in diabetic rats. Australian Journal of Basic and Applied Sciences 3 (3): 2963-2969.

Hertzler S.R., Clancy S.M. 2003. Kefir improves lactose digestion and tolerance in adults with lactose maldigestion. Journal of the American Dietetic Association 103 (5): 582-587. DOI: 10.1053/jada.2003.50111.

Holzapfel W.H., Haberer P., Snel J., Schillinger U., Huis in't Veld J. 1998. Overview of gut flora and probiotics. International Journal of Food Microbiology 41 (2): 85-101. DOI: 10.1016/S0168-1605(98)00044-0.

Jawad L.A., Al-Mukhtar M.A., Ahmed H.K. 2004. The relationship between haematocrit and some biological parameters of the Indian shad, Tenualosa ilisha (Family Clupidae). Animal Biodiversity and Conservation 27 (2): 478-483.

Merrifield L.D., Dimitroglou A., Foey A., Davies J.S., Baker M.T.R., Bøgwald J., Castex M., Ringø E. 2010. The cur- rent status and future focus of probiotic and prebiotic applications for salmonids. Aquaculture 302 (1-2): 1-18. DOI: 10.1016/j.aquaculture.2010.02.007.

Munilla-Moran R., Stark J.R., Barbour A. 1990. The role of exogenous enzymes in digestion in cultured turbot larvae (Scopthalmus maximus L.). Aquaculture 88 (3-4), 337-350. DOI: 10.1016/0044-8486(90)90159-K.

Satheeshkumar P., Ananthan G., Senthil Kumar D., Jagadeesan L. 2012. Haematology and biochemical parameters of different feeding behaviour of teleost fishes from Vellar estuary, India. Comparative Clinical Pathology 21 (6): 1187-1191. DOI: 10.1007/s00580-011-1259-7.

Scholl P.F., McCoy L., Kensler T.W., Groopman J.D. 2006. Quantitative analysis and chronic dosimetry of the aflatoxin $\mathrm{B}_{1}$ plasma albumin adduct Lys- $\mathrm{AFB}_{1}$ in rats by isotope dilution mass spectrometry. Chemical Research in Toxicology 19 (1): 44-49. DOI: 10.1021/tx050251r.

Schrezenmeir J., de Vrese M. 2001. Probiotics, prebiotics, and synbiotics - approaching a definition. American Journal of Clinical Nutrition 73 (2): 361S-364S.

Srichanun M., Tantikitti C., Vatanakul V., Musikarune P. 2012. Digestive enzyme activity during ontogenetic development and effect of live feed in green catfish larvae (Mystus nemurus Cuv. \& Val.). Songklanakarin Journal of Science and Technology 34 (3): 247-254.

Suzer C., Çoban D., Kamaci H.O., Saka Ş., Firat K., Otgucuoğlu Ö., Küçüksari H. 2008. Lactobacillus spp. bacteria as probiotics in gilthead sea bream (Sparus aurata L.) larvae: Effects on growth performance and digestive enzyme activities. Aquaculture 280 (1-4): 140-145. DOI: 10.1016/j.aquaculture.2008.04.020.

Turnbull J., Bell A., Adams C., Bron J., Huntingford F. 2005. Stocking density and welfare of cage farmed Atlantic salmon: application of a multivariate analysis. Aquaculture 243 (1-4): 121-132. DOI: 10.1016/j.aquaculture.2004. 09.022 .

Vaglio A., Landriscina C. 1999. Changes in liver enzyme activity in the teleost Sparus aurata in response to cadmium intoxication. Ecotoxicology and Environmental Safety 43 (1): 111-116. DOI: 10.1006/eesa.1999.1778.

Verschuere L., Rombaut G., Sorgeloos P., Verstraete W. 2000. Probiotic bacteria as biological control agents in aquaculture. Microbiology and Molecular Biology Reviews 64 (4): 655-671. DOI: 10.1128/MMBR.64.4.655-671.2000.

Ziaei-Nejad S., Rezaei M.H., Takami G.A., Lovett D.L., Mirvaghefi A.-R., Shakouri M. 2006. The effect of Bacillus spp. bacteria used as probiotics on digestive enzyme activity, survival and growth in the Indian white shrimp Fenneropenaeus indicus. Aquaculture 252 (2-4): 516-524. DOI: 10.1016/j.aquaculture.2005.07.021

Received: 27 August 2013

Accepted: 15 March 2014

Published electronically: 30 June 2014 